Georgia State University

ScholarWorks @ Georgia State University

Selections from the University Library Blog

University Library Publications

4-21-2015

\title{
Tracing a History of Atlanta's Public Transit
}

Joseph Hurley

Georgia State University, jhurley@gsu.edu

Follow this and additional works at: https://scholarworks.gsu.edu/univ_lib_blog

Part of the Infrastructure Commons, Library and Information Science Commons, Transportation Commons, and the Urban Studies and Planning Commons

\section{Recommended Citation}

Hurley, Joseph, "Tracing a History of Atlanta's Public Transit" (2015). Selections from the University Library Blog. 24.

https://scholarworks.gsu.edu/univ_lib_blog/24

This News Article is brought to you for free and open access by the University Library Publications at ScholarWorks @ Georgia State University. It has been accepted for inclusion in Selections from the University Library Blog by an authorized administrator of ScholarWorks @ Georgia State University. For more information, please contact scholarworks@gsu.edu. 


\section{Tracing a History of Atlanta's Public Transit}

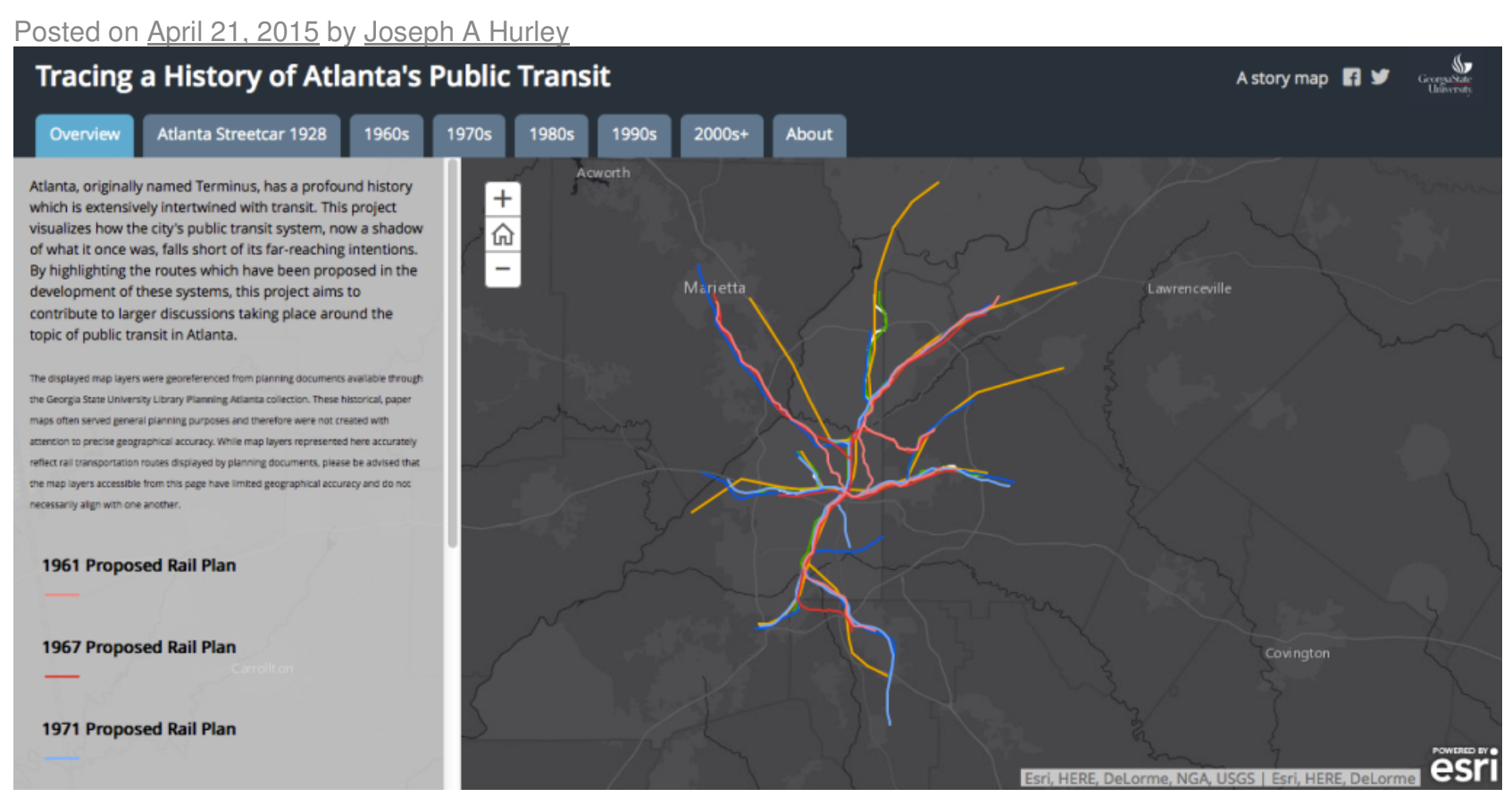

With MARTA expanding into Clayton County and the agency now resting on a more sound financial footing thanks to efforts by Keith Parker, MARTA appears to be on an upswing. As the concept of transit oriented development gains momentum, more areas across metro Atlanta appear open to the benefits of transit, leading some to conclude that MARTA may expand further out across the region. However, since MARTA's 1960 s inception it was planned to be a far-reaching, regional transit system. In each decade since MARTA's beginnings, the agency proposed routes that would have made MARTA a truly expansive system. A number of these proposed MARTA routes can now be visualized in Tracing a History of Atlanta's Public Transit, a digital project by a team of Student Innovation Fellowship (SIF) students working in the University Library's CURVE.

This SIF team gathered MARTA proposals from the library's Planning Atlanta collection, located information from the Georgia Power streetcar system era, and collected material about the Atlanta Streetcar and the Atlanta Beltline. By tracing each proposed route, this team turned this information into geospatial data and created Tracing a History of Atlanta's Public Transit, which clearly shows MARTA's far-reaching intentions. As the state and the region begin to look more favorably on transit investment, this project aims to contribute to larger discussions taking place around the topic of public transit in Atlanta. 
http://webapps.library.gsu.edu/blogs/library/2015/04/21/tracing-a-history-of-atlantas-public-transit/ 